\title{
Bone mineral density and fractures in institutionalised children with epilepsy and intellectual disability
}

Citation for published version (APA):

Berkvens, J. J. L., Mergler, S., Beerhorst, K., Verschuure, P., Tan, I. Y., Majoie, H. J. M., \& van den Bergh, J. P. W. (2021). Bone mineral density and fractures in institutionalised children with epilepsy and intellectual disability. Journal of Intellectual Disability Research, 65(11), 962-970.

https://doi.org/10.1111/jir.12880

Document status and date:

Published: 01/11/2021

DOI:

10.1111/jir.12880

Document Version:

Publisher's PDF, also known as Version of record

Document license:

Taverne

Please check the document version of this publication:

- A submitted manuscript is the version of the article upon submission and before peer-review. There can be important differences between the submitted version and the official published version of record.

People interested in the research are advised to contact the author for the final version of the publication, or visit the DOI to the publisher's website.

- The final author version and the galley proof are versions of the publication after peer review.

- The final published version features the final layout of the paper including the volume, issue and page numbers.

Link to publication

\footnotetext{
General rights rights.

- You may freely distribute the URL identifying the publication in the public portal. please follow below link for the End User Agreement:

www.umlib.nl/taverne-license

Take down policy

If you believe that this document breaches copyright please contact us at:

repository@maastrichtuniversity.nl

providing details and we will investigate your claim.
}

Copyright and moral rights for the publications made accessible in the public portal are retained by the authors and/or other copyright owners and it is a condition of accessing publications that users recognise and abide by the legal requirements associated with these

- Users may download and print one copy of any publication from the public portal for the purpose of private study or research.

- You may not further distribute the material or use it for any profit-making activity or commercial gain

If the publication is distributed under the terms of Article $25 \mathrm{fa}$ of the Dutch Copyright Act, indicated by the "Taverne" license above, 


\title{
Bone mineral density and fractures in institutionalised children with epilepsy and intellectual disability
}

\author{
J. J. L. Berkvens, ' D S. Mergler, ${ }^{2,3}$ (D) K. Beerhorst, ${ }^{4}$ (D) P. Verschuure, ${ }^{5}$ iD I. Y. Tan, ${ }^{1}$ \\ H. J. M. Majoie $6,7,8$ iD \& J. P. W. van den Bergh 9,10 \\ I Department of Residential Care, Epilepsy Centre Kempenhaeghe, Heeze, The Netherlands \\ 2 Medical Department, ASVZ, Care and Service Centre for People with Intellectual Disabilities, Sliedrecht, The Netherlands \\ 3 Department of General Practice and Intellectual Disability Medicine, Erasmus University Medical Centre, Rotterdam, The \\ Netherlands \\ 4 Department of Neurology, Zuyderland Medical Centre, Heerlen, The Netherlands \\ 5 Laboratory for Clinical Chemistry and Pharmacology, Epilepsy Centre Kempenhaeghe, Heeze, The Netherlands \\ 6 Department of Neurology, Academic Centre for Epileptology Kempenhaeghe, Maastricht University Medical Centre, Heeze, The \\ Netherlands \\ 7 MHeNs School for Mental Health and Neuroscience, Maastricht University Medical Centre, Maastricht, The Netherlands \\ 8 School of Health Professions Education, Faculty of Health, Medicine and Life Sciences, Maastricht University, Maastricht, the \\ Netherlands \\ 9 Department of Internal Medicine, VieCuri Medical Centre, Venlo, The Netherlands \\ 10 NUTRIM School of Nutrition and Translational Research in Metabolism, Maastricht University Medical Centre, Maastricht, The \\ Netherlands
}

\begin{abstract}
Background Long-term use of antiseizure drugs is associated with a low bone mineral density (BMD) and an increased fracture risk. The literature regarding institutionalised children on chronic antiseizure drugs is limited. Therefore, the aim of this cross-sectional study is to evaluate the prevalence of low BMD and the history of fractures in institutionalised children with epilepsy and intellectual disability (ID).

Methods A dual-energy X-ray absorptiometry of lumbar spine (LI-L4) and hip was performed in 24 children, residing in a long-stay care facility in the Netherlands. Additionally, serum concentrations of albumin, calcium and 25-hydroxyvitamin $\mathrm{D}$ were
\end{abstract}

Correspondence: Jessica J. L. Berkvens MSc., Department of Residential Care, Epilepsy Centre Kempenhaeghe, PO Box 6I, 5590 AB Heeze, The Netherlands (e-mail: berkvensi@kempenhaeghe.nl). determined. Data on fractures were retrospectively extracted from the medical files.

Results Ages of the children (I4 male and Io female) ranged from 5 to 17 years with a mean age of 13.0 $( \pm 3.2)$. The criteria of the International Society for Clinical Densitometry (ISCD) were used for classification of bone mineral disorders. Eight $(33.3 \%)$ children had a normal BMD ( $Z$ score $>-2.0)$. Of the 16 children with a low BMD ( $Z$-score $\leq-2.0$ ), three were diagnosed as osteoporotic, based on their fracture history. Ten children $(4 \mathrm{I} .7 \%)$ were reported to have at least one fracture in their medical history. Serum concentrations of albumin-corrected calcium (2.28-2.50 $\mathrm{mmol} / \mathrm{L})$ and (supplemented) vitamin D (I6-I37 nmol/L) were within the normal range. Conclusions This study demonstrated that $67 \%$ of institutionalised children with epilepsy and ID had low BMD and $42 \%$ had a history of at least one 
J. J. L. Berkvens et al. - BMD and fractures in children with epilepsy and ID

fracture, despite supplementation of calcium and vitamin $\mathrm{D}$ in accordance with the Dutch guidelines.

Keywords Antiepileptic drugs (AEDs), Bone mineral density (BMD), Children, Dual-energy X-ray absorptiometry (DXA), Epilepsy, Intellectual Disability (ID), Osteoporosis

\section{Background}

Epilepsy is one of the most common neurological disorders, affecting people of all ages. Worldwide, approximately 50 million people are diagnosed with epilepsy (WHO 20I9). Treatment often consists of life-long therapy with antiseizure drugs. However, antiseizure drugs are shown to be associated with a decreased bone mineral density (BMD) and an increased fracture risk (Vestergaard 2005; Lee et al. 20IO; Shen et al. 20I4), especially when used in polytherapy (El-Hajj Fuleihan et al. 2008; Fong et al. 2018). As the peak bone mass of humans is reached between the age of 20 and 30 years, childhood is a critical period for bone mass development. Exposure to antiseizure drugs during this period may lead to a lower peak bone mass and as a result, an increased fracture risk later in life (Sheth 2004). Children with epilepsy who are institutionalised may be more prone to several other risk factors which could affect BMD, such as feeding difficulties and malnutrition (Henderson et al. 2002; Sharawat and Sitaraman 2016), severe neurological impairments (Henderson et al. 2002), immobility (Jaffe et al. 2005; Tosun et al. 20I7) and less sunlight exposure (Ko et al. 2020). Additionally, BMD is found to be significantly lower among persons with intellectual disability (ID) (Coppola et al. 20I2; Tosun et al. 20I7). The literature regarding BMD and fractures in institutionalised children on chronic antiseizure drugs is limited.

Therefore, the aim of this study is to evaluate the prevalence of low BMD and the history of fractures in institutionalised children with epilepsy and ID.

\section{Methods}

\section{Participants}

This cross-sectional study included children ( $<$ I 8 years) from a long-stay care facility for people with epilepsy and ID in the Netherlands. All children have epilepsy, caused by a variety of factors (i.e. genetic, structural, metabolic, immunologic, infectious or unknown) and some degree of ID, ranging from mild to profound. All children were of the same ethnicity (White).

The study was approved by the local medical ethical committee (METC I6.04), and informed consent was obtained from the legal representatives (in most cases parents) of the children. During measurements, all children were informed verbally and guided by a familiar nurse and/or family member. Procedures were stopped when a child refused to cooperate or showed significant signs of resistance.

\section{Data collection}

In November 2016, all 33 children were invited to undergo a dual-energy X-ray absorptiometry-scan (DXA) of hip and lumbar spine (LI-L4) and blood samples were taken. Of these, 26 children (78.8\%) participated. The legal representative(s) of two children had refused because of the presence of anxiety/agitation. In the other five children the reasons for refusal were not reported.

\section{Demographic and epilepsy characteristics}

Demographic and epilepsy characteristics were collected through the medical records. Demographic characteristics included age (years), sex (male/ female), ID (mild/moderate/severe/profound), Tanner stage (pre-pubertal/pubertal/post-pubertal), weight $(\mathrm{kg})$, height $(\mathrm{m})$, nutritional status (regular food/tube-fed), mobility (not able to walk/walk with aid/walk without aid), current use of calcium, vitamin $\mathrm{D}$ and bisphosphonates and Barthel index (0-20).

The Barthel index is a ten-item scale which assesses a person's daily functioning in activities of daily living (ADL). A score of o means total dependency on others, and the maximum score of 20 implies complete independency in ADL. As for Tanner stages, the most recent ( $<6$ months) assessments of the paediatrician were used for classification; stage I (GI/MI) was classified as pre-pubertal, stages 2 to 4 as pubertal and $5\left(\mathrm{G}_{5} / \mathrm{M}_{5}\right)$ as post-pubertal (Marshall and Tanner 1969; Marshall and Tanner I970). In girls, onset of breast development (M2) before the age of eight was considered as early puberty and after the age of 12 as late puberty. In boys, onset of testicular

(C) 202 I MENCAP and International Association of the Scientific Study of Intellectual and Developmental Disabilities and John Wiley \& Sons Ltd 
J. J. L. Berkvens et al. - BMD and fractures in children with epilepsy and ID

enlargement (G2) before the age of nine was considered as early puberty and after the age of fourteen as late puberty (van den Akker 2016). Furthermore, body mass index was calculated by dividing weight by the square of height and was classified using the WHO child growth references 5-19 years. A cut-off score for thinness was a body mass index less than $-2 S D$. Overweight and obesity were classified using cut-off scores of $>+$ I $S D$ and $>+2 S D$, respectively (WHO 2007).

All epilepsy characteristics in the medical records had been established by neurologists. All children had been diagnosed with epilepsy in the past, based on the presentation of seizures and/or diagnostic tests. Collected data for this study included cause of epilepsy (genetic, structural, metabolic, immunologic, infectious or unknown), age of onset, duration and current antiseizure drug use.

\section{Bone mineral density}

All measurements were made with the same densitometer (Hologic, Discovery A [S/N 80847]). $\mathrm{BMD}$ was expressed as the amount of mineral (g) divided by the area scanned $\left(\mathrm{cm}^{2}\right)$ and as $Z$-scores. $Z$-scores compare data of the children with age-matched, race-matched and sex-matched normative data provided by the manufacturer.

The criteria of the International Society for Clinical Densitometry (ISCD) were used to classify bone mineral disorders (Gordon et al. 20I4). A $Z$-score equal to or below $\mathbf{- 2 . 0}$ was considered as low BMD.

The diagnosis of osteoporosis was made based on the following criteria (Gordon et al. 2014):

- Low BMD ( $Z$-score $\leq-2.0)$ AND a clinically significant fracture history:

I Two or more long bone fractures under the age of Io years; and

2 Three or more long bone fractures under the age of 19 years.

\section{Serum concentrations}

Blood samples were taken (simultaneously with periodical laboratory testing in January/February) and serum concentrations of calcium $(\mathrm{mmol} / \mathrm{L})$, albumin (g/L) and 25-hydroxyvitamin D (nmol/L) were defined. Serum concentrations of calcium were corrected for albumin if the level of albumin was below $35 \mathrm{~g} / \mathrm{L}$.

\section{Fractures}

Information on clinical fractures was retrospectively extracted from radiology reports in the medical records. All clinical fractures were classified according to the ICD-IO. Fractures of hip/femur

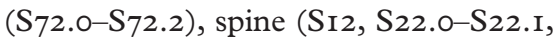
$\mathrm{S}_{32.0}-\mathrm{S}_{32.2}, \mathrm{~S}_{32.7}-\mathrm{S}_{32.8}$, forearm/wrist $\left(\mathrm{S}_{52}\right)$ and upper $\mathrm{arm} /$ humerus $\left(\mathrm{S}_{42.2}-\mathrm{S}_{42}\right.$.4) were considered as major osteoporotic fractures. No vertebral fracture assessments were performed.

\section{Statistical analysis}

Data are presented as means $( \pm S D)$ or as frequencies (percentages). Differences in serum concentrations of albumin-corrected calcium and 25-hydroxyvitamin D between groups (fractures yes/no and low/normal BMD) were compared using the Student $t$ test (parametric) or Mann-Whitney $U$ test (nonparametric), after checking for normality (histogram, Q-Q plots and boxplot).

All statistical tests were two-tailed with a level of significance of.05. Statistical analyses were conducted using SPSS version 26 (IBM Corporation, UK).

\section{Results}

\section{Demographic and epilepsy characteristics}

From a total of 26 children, two were excluded due to unreliable scans of hip and lumbar spine (movement during the scans). Therefore, 24 children (I4 male and Io female) were successfully measured by DXA at the hip and/or lumbar spine. In one child, hip measurements were missing due to movement, and in five children, lumbar spine was not measured, due to osteosynthesis material $(n=\mathrm{I})$ or movement during the $\operatorname{scan}(n=4)$.

Demographic characteristics are summarised in Table I. Age ranged from 5 to 17 years (mean I3.O \pm 3.2 ) and residence duration from 3 months to I 2 years (mean $5.1 \pm 3.5$ years). Four children (I6.7\%) were wheelchair dependent. The rest were able to walk, with $(n=5)$ or without aid $(n=\mathrm{I} 5)$. None of the children were completely independent in ADL (Barthel index ranged from 0 to 17 with a 
J. J. L. Berkvens et al. • BMD and fractures in children with epilepsy and ID

Table I Demographic characteristics of 24 children with epilepsy and intellectual disability

\begin{tabular}{|c|c|c|}
\hline & $n(\%)$ & Mean (SD) \\
\hline \multicolumn{3}{|l|}{ Sex } \\
\hline Male & $14(58.3)$ & \\
\hline Female & $10(4 \mid .7)$ & \\
\hline Age (in years) & & $13.0(3.2)$ \\
\hline Duration of residency (in years) & & $5.1(3.5)$ \\
\hline \multicolumn{3}{|l|}{ Intellectual disability } \\
\hline Mild (IQ 55-70) & $2(8.3)$ & \\
\hline Moderate (IQ 40-55) & $8(33.3)$ & \\
\hline Severe (IQ 25-40) & $8(33.3)$ & \\
\hline Profound (IQ < 25) & $6(25.0)$ & \\
\hline \multicolumn{3}{|l|}{ Tanner stage } \\
\hline Unknown & $3(12.5)$ & \\
\hline Pre-pubertal & $9(37.5)$ & \\
\hline Pubertal & $6(25.0)$ & \\
\hline Post-pubertal & $6(25.0)$ & \\
\hline \multicolumn{3}{|l|}{ BMI category ${ }^{\dagger}$} \\
\hline Thinness $(<-2 S D)$ & I (4.2) & \\
\hline Normal weight & $19(79.2)$ & \\
\hline Overweight $(>+I S D)$ & $4(16.7)$ & \\
\hline \multicolumn{3}{|l|}{ Nutritional status } \\
\hline Regular food & $18(75.0)$ & \\
\hline Regular food (plus tube-fed) & $4(16.7)$ & \\
\hline Tube-fed (plus regular food) & $2(8.3)$ & \\
\hline \multicolumn{3}{|l|}{ Mobility } \\
\hline Not able to walk & $4(16.7)$ & \\
\hline Walk with aid & $5(20.8)$ & \\
\hline Walk without aid & $15(62.5)$ & \\
\hline
\end{tabular}

${ }^{+}$Classification according to the WHO child growth references 5-19 years.

median of 8.5$)$. In all six children (25.0\%) with a feeding tube, tube feeding was used in combination with regular food. One child was diagnosed with early puberty. As for bone status, none of the children were previously diagnosed with osteoporosis or treated with bisphosphonates.

Age of onset of epilepsy ranged from birth to 4 years and 4 months (mean I. $3 \pm$ I.3 years).

Duration of epilepsy, at the time of the study, ranged from 4 years to 17 years and 4 months. All children were on antiseizure drugs (Table 2 ; mean number of drugs $2.6 \pm$ I.I). Four children (I6.7\%) were on monotherapy [valproic acid $(2 \times)$, topiramate and oxcarbazepine]. Eleven children (45.8\%) were prescribed one enzyme-inducing antiseizure drug and $22(91.7 \%)$ were prescribed one or more nonenzyme-inducing drugs.
Table 2 Aetiology of epilepsy and the use of antiseizure drugs in 24 children with epilepsy and intellectual disability

\begin{tabular}{|c|c|c|}
\hline & & $N(\%)$ \\
\hline \multicolumn{3}{|c|}{ Aetiology of epilepsy } \\
\hline \multicolumn{2}{|c|}{ Genetic } & $12(50.0)$ \\
\hline \multicolumn{2}{|l|}{ Structural } & $3(12.5)$ \\
\hline \multicolumn{2}{|l|}{ Infectious } & $2(8.3)$ \\
\hline \multicolumn{2}{|l|}{ Unknown } & $7(29.2)$ \\
\hline \multicolumn{3}{|c|}{ Number of antiseizure drugs } \\
\hline \multicolumn{2}{|c|}{ One } & $4(16.7)$ \\
\hline \multicolumn{2}{|l|}{ Two } & $7(29.2)$ \\
\hline \multicolumn{2}{|l|}{ Three } & $7(29.2)$ \\
\hline \multicolumn{2}{|l|}{ Four } & $6(25.0)$ \\
\hline \multicolumn{3}{|c|}{ Enzyme inducing ${ }^{\dagger}$} \\
\hline \multicolumn{2}{|c|}{ Carbamazepine } & I (4.2) \\
\hline \multicolumn{2}{|c|}{ Phenobarbital $\quad$ I (4.2) } & \\
\hline \multirow{2}{*}{$\begin{array}{c}\text { Weak } \\
\text { Topiramate }\end{array}$} & Oxcarbazepine & $2(8.3)$ \\
\hline & $7(29.2)$ & \\
\hline \multicolumn{3}{|c|}{ Non-enzyme inducing ${ }^{\dagger}$} \\
\hline \multicolumn{3}{|c|}{ Acetazolamide } \\
\hline & Clobazam & II (45.8) \\
\hline & Clonazepam & I (4.2) \\
\hline & Ethosuximide & I (4.2) \\
\hline & Lamotrigine & $4(16.7)$ \\
\hline & Levetiracetam & $7(29.2)$ \\
\hline & Perampanel & $3(12.5)$ \\
\hline & Stiripentol & $2(8.3)$ \\
\hline & Valproic acid & $19(79.2)$ \\
\hline & Zonisamide & $4(16.7)$ \\
\hline
\end{tabular}

Antiseizure drugs are used in various combinations: due to polytherapy and/or the use of both enzyme and non-enzyme inducers, total numbers add up to more than $100 \%$.

\section{Bone mineral density}

Based on the $Z$-scores (Table 3), eight children $(33.3 \%)$ had a normal BMD, and I6 children (66.7\%) a low BMD $(Z$-score $\leq-2.0)$. In view of the fracture history, three of the latter group (I2.5\%) were considered as osteoporotic according to the criteria of the ISCD (Gordon et al. 20I4). They were 8, Io and I 7 years old at the time of BMD measurements.

\section{Serum concentrations}

Except for one child, all (95.8\%) were on vitamin D supplementation at the time of the study with a mean duration of 4.7 years $( \pm 3 . I)$. Ten children used a combination of vitamin $\mathrm{D}$ and calcium. In one child $(4.2 \%)$, albumin was below $35 \mathrm{~g} / \mathrm{L}$. Mean serum concentration of albumin-corrected calcium and 
J. J. L. Berkvens et al. - BMD and fractures in children with epilepsy and ID

Table 3 Bone mineral density (BMD) and $Z$-scores $(n=24)$

\begin{tabular}{|c|c|c|c|c|}
\hline & $n$ & $\begin{array}{c}\left.\text { BMD (in } \mathrm{g} / \mathrm{cm}^{2}\right) \\
\text { Mean (SD) }\end{array}$ & $\begin{array}{c}\text { Z-score } \\
\text { Mean (SD) }\end{array}$ & $\begin{array}{c}\text { Low BMD (Z-score } \leq-2.0) \\
n(\%)\end{array}$ \\
\hline Lumbar spine (LI-L4) & 19 & $0.725(0.151)$ & $-1.0(1.3)$ & $4(2 I . I)$ \\
\hline Femoral neck & 23 & $0.594(0.116)$ & $-2.5(1.2)$ & $15(65.2)$ \\
\hline Total hip & 23 & $0.667(0.142)$ & $-2.3(1.2)$ & $\begin{array}{l}15(65.2) \\
16(66.7)\end{array}$ \\
\hline Total & & & & \\
\hline
\end{tabular}

25-hydroxyvitamin D were 2.4I ( \pm 0.06$) \mathrm{mmol} / \mathrm{L}$ and $87.2( \pm 33.3) \mathrm{nmol} / \mathrm{L}$, respectively. Three children had a 25-hydroxyvitamin $\mathrm{D}$ concentration below $50 \mathrm{nmol} / \mathrm{L}(\mathrm{I} 6,4 \mathrm{I}$ and $48 \mathrm{nmol} / \mathrm{L})$. One of them (4I nmol/L) was not on vitamin D supplementation at the time of the study. The child with the lowest serum concentration had a normal BMD and no historic fractures.

Serum concentrations of albumin-corrected calcium and 25-hydroxyvitamin $\mathrm{D}$ did not differ between children with a low or a normal BMD, and no differences in serum concentrations were found between children with and without fractures.

\section{Fractures}

Ten children (4I.7\%) were reported to have had at least one fracture in their medical history. According to the medical files, seven children had suffered one fracture [humerus, forearm $\left(3^{\times}\right)$, femur, lower leg and toe], one child had suffered two fractures (finger and toe) and one child nine fractures [forearm, thumb, fingers $\left(3^{x}\right)$, lower leg, talus, foot and great toe]. One child had sustained multiple fractures, caused by a trauma incident, but they were not further specified. Of the eight children diagnosed with a normal BMD, one child (I2.5\%) had a history of fracture vs. nine of the sixteen children with a low BMD (56.3\%).

Three fractures had been caused by an accidental trauma (I6.7\%); one finger had been fractured during a ballgame, one finger had been caught between the door and one foot had been fractured by bumping it to a doorframe. Seven fractures $(38.9 \%)$ had been caused by a fall (humerus, forearm (3x), thumb, femur, lower leg), of which at least three (forearm, thumb, lower leg) were the result of a seizure. Circumstances of the eight remaining fractures (forearm, finger (2x), lower leg, talus, great toe, toe $(2 \mathrm{x}))$ were not reported $(44 \cdot 4 \%)$.

Five fractures $(27.8 \%)$ are considered as major osteoporotic fractures, based on their locations (humerus, forearm (4x)). Four of these five (the cause of one fractured forearm was unknown), had been caused by a low-level fall from standing height or less.

\section{Discussion}

In this study, we found a high prevalence of low BMD $(67 \%)$ and historic fractures $(42 \%)$ in institutionalised children with epilepsy and ID.

The total number of fractures during lifetime, though, might be slightly underestimated as all children lived at home before they moved to the care facility. Age at admittance in the care facility ranged from I.O to I3.8 years. Fractures (especially minor ones) that occurred before institutionalisation may not have been documented in the medical files. Nevertheless, at least $4 \mathrm{I} .7 \%$ of the children had suffered from one or more fractures during their lives. This is higher than what Simm et al. (2017) found $(34.8 \%)$ in children with at least I year of antiseizure drug exposure, but they excluded children who suffered from neurodevelopmental disorders or immobility. Overall, in the Netherlands, the incidence of fractures in children between 6 and 16 years of age is estimated at $40 \%$ for males and $28 \%$ for females (Federatie van Medisch Specialisten 20I9). In our study, those percentages were 50\% and 30\%, respectively. However, three-quarter of our study participants has not yet reached the age of I6. In addition, the peak of fractures for males lies around the age of I 5 and for females around the age of 12 (Verhaar and van Mourik 2008). Half of our study participants (eight males younger than I5 and four females younger than 12) have not yet reached the age of peak 
J. J. L. Berkvens et al. - BMD and fractures in children with epilepsy and ID

fracture incidence. This implies that it may be expected that the proportion of children with a fracture until the age of 16 in our cohort will further increase.

In our study, circumstances of eight fractures were not reported. In those cases, we are not able to differentiate between low and high impact fractures. Overall, based on the locations, five fractures (27.8\%) were considered major osteoporotic fractures. The other had been minor fractures, involving mainly fingers and toes. In children that already suffer from multiple physical disabilities, even minor fractures may have a major impact on daily living and cause pain, discomfort, stiffness and further limitations.

In the study of Shiek Ahmad et al. (2012), half of the falls $(49 \%)$ had been caused by a seizure and about one-third of the fractures $(31 \%)$ in persons on antiseizure drugs had been seizure-related. In our study, seven fractures were reported to be caused by a fall $(38.9 \%)$. At least three of these falls had been the result of a seizure. Presumably, many seizures go unwitnessed and it is difficult to determine whether a fall is seizure-related or not. For this reason, it is hard to determine whether a fracture is a result of a seizure or of the fall itself. Grzonka et al. (2019) performed a systematic review of the literature regarding fractures as a direct consequence of convulsive seizures in adults and identified 39 studies. Most frequently reported in these studies were bilateral posterior fracture-dislocations of the shoulders, thoracic and lumbar vertebral compression fractures, skull and jaw fractures and bilateral femoral neck fractures. In our study, none of these fractures were reported, suggesting that the fractures might be more likely to be a consequence of the fall, rather than the seizure itself although seizure-related fractures may occur at other locations in adults than in children.

Gniatkowska-Nowakowska (2010) observed a group of 126 children with epilepsy. During 5 years, I $7 \%$ of the children on monotherapy had suffered a fracture, vs. $49 \%$ of the children on add-on therapy. In our study, percentages of children with fractures for mono- and polytherapy were 25.0 and $45.0 \%$ respectively, but this should be interpreted with caution due to the small number of children on monotherapy in our study $(n=4)$.

The combination of bone mineral disorders (osteopenia/osteoporosis) and the use of antiseizure drugs has first been described around 1970 (Dent et al. 1970; Linde et al. 1971; Hahn 1976) and included cytochrome $\mathrm{P} 450$-inducing antiseizure drugs, such as carbamazepine, phenobarbital, phenytoin and primidone. But also newer antiseizure drugs with minimal or no enzyme-inducing effects seem to have an effect on bone metabolism, even though not all results are consistent (Fan et al. 20I6; Diemar et al. 20I9; Mitta et al. 20I9). In our study, no conclusions can be drawn regarding the effects of enzyme-inducing vs. non-enzyme-inducing drugs, as only one child used carbamazepine and one child phenobarbital. The rest of the children were on antiseizure drugs with minimal (topiramate/ oxcarbazepine) to no enzyme-inducing effects.

A low BMD was found in $67 \%$ of the children. In the same care facility, the prevalence of low BMD in adults was $80 \%$, and one-third was diagnosed with osteoporosis (Beerhorst et al. 2013). As childhood is a critical period for bone mass development, the proportion of children with low bone mass $(67 \%)$ or osteoporosis (12.5\%) is alarming. Similar percentages of children on antiseizure drugs with osteoporosis were found by Gniatkowska-Nowakowska (20I0) (7.1\%) and Coppola et al. (2009) (14.6\%), although both studies applied different classification methods and did not include fracture history in the diagnosis.

A complicating factor in diagnostics is the accuracy of the DXA scans. Mergler et al. (2OI2) studied a group of children with severe neurological impairment and ID and found a mean number of 5.3 distorting factors and artefacts per child. The most frequently occurring factors they identified were movement during measurement, scoliosis, contractures, gastrostomy catheters, aberrant body composition and a height below the fifth centile for age. In our study, two children were excluded due to movement during the scans, Io children had a form of scoliosis, six children had a gastrostomy catheter and five children had a height below the fifth centile. The presence of contractures and aberrant body composition were not reported or assessed in our study. However, one child was diagnosed with early puberty which could have affected the results of the DXA. As distorting factors and artefacts can lead to both overestimation and underestimation of $\mathrm{BMD}$, it is uncertain how this influenced the outcomes in our study. Most of the factors that were identified will be more likely to affect BMD of the spine than BMD of the hip.

In a meta-analysis including nine studies, a significant association was found between antiseizure 
J. J. L. Berkvens et al. - BMD and fractures in children with epilepsy and ID

drug treatment and a decreased 25-hydroxyvitamin $\mathrm{D}$, in persons without vitamin $\mathrm{D}$ supplementation (Zhang et al. 2015). In our study, 25-hydroxyvitamin $\mathrm{D}$ levels had been measured in the middle of the winter, when they are at the lowest, and we identified only three children with a level below $50 \mathrm{nmol} / \mathrm{L}$. The rest of the children had a sufficient level of serum vitamin D (56-I37 nmol/L), but it has to be noted that except for one child, all (95.8\%) were on vitamin D supplementation at the time of the study. The higher tendency for vitamin $\mathrm{D}$ supplementation may be explained by a previous study undertaken in the care facility. Between 2012 and 2014,

Snoeijen-Schouwenaars et al. (2015) studied the effects of vitamin D supplementation. Some of the children participated in that study, as well as in the current study. Presumably, the previous study led to an increased awareness among general practitioners regarding supplementation. Vitamin D supplements were prescribed, as part of standard care, in doses which were at least equal to the amount recommended by the Dutch guidelines. Eight fractures $(44.4 \%)$, in four children, occurred after the prescription of vitamin D (ranging from 8 months to 9 years and 4 months).

Serum concentrations of albumin-corrected calcium (2.28-2.50 $\mathrm{mmol} / \mathrm{L})$ of the children were within the normal range, similar with the findings in other studies (Gniatkowska-Nowakowska 20I0; Rauchenzauner et al. 20I0; Serin et al. 2015). However, those studies excluded institutionalised children or children with physical and/or intellectual disabilities.

\section{Limitations}

Despite our best efforts to contribute to the literature regarding $\mathrm{BMD}$ and fractures in institutionalised children on chronic antiseizure drugs, we acknowledge several limitations of our study.

First of all, it was a cross-sectional study at a single institute. The number of participants was small and they represent a complex, heterogeneous population with differences regarding sex, age, nutritional status, mobility, type and number of antiseizure drugs, and so forth. As all children have a different background and medical history, we cannot rule out additional factors that may have affected BMD and/or the number of fractures, such as the influence of genetic syndromes and comorbidity, or the possibility of physical abuse before institutionalisation. Due to these uncertainties in background and medical history and the heterogenicity of our study group, our findings may not be completely generalisable to other institutionalised children with epilepsy and ID.

Although the main focus of our report was on the chronic use of antiseizure drugs, we emphasise the multifactorial nature of the causes of osteoporosis and recognise several other risk factors in our study group, for instance, physical activity. Nine children $(37.5 \%)$ were not able to walk independently, and the median score on the Barthel index was 8.5. Even though these parameters do not necessarily reflect a child's activity level, they may imply a lower physical activity.

Despite limitations regarding heterogenicity of the study group and generalisability, our results should be taken seriously. Screening of BMD in children with epilepsy is not part of routine care in the Netherlands. Although a DXA could be helpful to identify children who are at risk for fractures, it should only be performed when the results impact further treatment. However, there is a lack of evidence regarding treatment of low BMD in children. In adults, the first-choice treatment for low BMD ( $T$ score $\leq-2.5$ ), is the use of bisphosphonates (CBO 20II). For children, caution is advised with regard to prescribing bisphosphonates, due to the limited data on the (late) effects and the duration of treatment (Saraff and Hogler 2015; Simm et al. 2018). Consequently, prophylactic bisphosphonate therapy (treating low BMD in the absence of fractures) is not recommended (Simm et al. 2018).

Regardless of DXA results, it is advised to take safety measures to prevent falls and to educate caregivers. These interventions, as well as a careful (re-)evaluation of prescribed antiseizure drugs and the feasibility of lifestyle changes, should be part of the care plan. In order to optimise bone health in children who are at risk of fractures, physical activity, especially weight-bearing exercises (Gunter et al. 2012) and an adequate calcium and vitamin D intake remain important (Ko et al. 2020). But above all, more research is needed towards optimal treatment options. We undertook this study to contribute to the literature and to raise awareness about the risk of bone mineral disorders in children on chronic antiseizure drugs. 
J. J. L. Berkvens et al. - BMD and fractures in children with epilepsy and ID

\section{Conclusion}

The prevalence of a low BMD in institutionalised children with epilepsy and ID is found to be high $(67 \%)$. Osteoporosis might already be present at a very young age (the youngest in our study was 8 years), despite vitamin $\mathrm{D}$ supplementation in accordance with the Dutch guidelines. This study emphasises the need for more understanding of this complex population, in order to adequately manage bone mineral problems. Further research in a larger population, with more accurate fracture data and a focus on treatment is needed, to gain more insight and establish optimal treatment options in children who are at risk of bone mineral disorders.

\section{Conflict of interest}

J. v. d. B. has received research funding from UCB, Eli Lilly and Amgen not related to the work presented in this paper. The other authors have no conflicts of interest to disclose. We confirm that we have read the Fournal's position on issues involved in ethical publication and affirm that this report is consistent with those guidelines.

\section{Source of Funding}

This research did not receive any specific grant from funding agencies in the public, commercial or notfor-profit sectors.

\section{Data Availability Statement}

The data that support the findings of this study are available from the corresponding author upon reasonable request.

\section{References}

Beerhorst K., Tan I. Y., De Krom M., Verschuure P. \& Aldenkamp A. P. (2013) Antiepileptic drugs and high prevalence of low bone mineral density in a group of inpatients with chronic epilepsy. Acta Neurologica Scandinavica I28, 273-80.

CBO (20II) Richtlijn osteoporose en fractuurpreventie. Available at: https://www.volksgezondheidenzorg.info/ sites/default/files/cbo_richtlijn_osteoporose-enfractuurpreventie-20II.pdf (retrieved 27 July 2020).
Coppola G., Fortunato D., Auricchio G., Mainolfi C., Operto F. F., Signoriello G. et al. (2009) Bone mineral density in children, adolescents, and young adults with epilepsy. Epilepsia 50, 2140-6.

Coppola G., Fortunato D., Mainolfi C., Porcaro F., Roccaro D., Signoriello G. et al. (2012) Bone mineral density in a population of children and adolescents with cerebral palsy and mental retardation with or without epilepsy. Epilepsia 53, $2172-7$.

Dent C. E., Richens A., Rowe D. J. \& Stamp T. C. (I970) Osteomalacia with long-term anticonvulsant therapy in epilepsy. British Medical fournal 4, 69-72.

Diemar S. S., Sejling A. S., Eiken P., Andersen N. B. \& Jørgensen N. R. (2019) An explorative literature review of the multifactorial causes of osteoporosis in epilepsy. Epilepsy \& Behavior 100, I065II.

El-Hajj Fuleihan G., Dib L., Yamout B., Sawaya R. \& Mikati M. A. (2008) Predictors of bone density in ambulatory patients on antiepileptic drugs. Bone $\mathbf{4 3}$, I49-55.

Fan H. C., Lee H. S., Chang K. P., Lee Y. Y., Lai H. C., Hung P. L. et al. (2016) The impact of anti-epileptic drugs on growth and bone metabolism. International fournal of Molecular Sciences 17, I-22.

Federatie van Medisch Specialisten (2019) Richtlijn fracturen bij kinderen. Available at: https://richtlijnendatabase.nl/ richtlijn/fracturen_bij_kinderen/startpagina.html (retrieved 27 July 2020).

Fong C. Y., Kong A. N., Noordin M., Poh B. K., Ong L. C. \& Ng C. C. (20I8) Determinants of low bone mineral density in children with epilepsy. European fournal of Paediatric Neurology 22, 155-63.

Gniatkowska-Nowakowska A. (2010) Fractures in epilepsy children. Seizure 19, 324-5.

Gordon C. M., Leonard M. B. \& Zemel B. S. (2014) 2013 Pediatric Position Development Conference: executive summary and reflections. Fournal of Clinical Densitometry I7, 219-24.

Grzonka P., Rybitschka A., De Marchis G. M., Marsch S. \& Sutter R. (2019) Bone fractures from generalized convulsive seizures and status epilepticus - a systematic review. Epilepsia 60, 996-1004.

Gunter K. B., Almstedt H. C. \& Janz K. F. (2012) Physical activity in childhood may be the key to optimizing lifespan skeletal health. Exercise and Sport Sciences Reviews 40, $13-2 \mathrm{I}$.

Hahn T. J. (1976) Bone complications of anticonvulsants. Drugs I2, 2OI-II.

Henderson R. C., Lark R. K., Gurka M. J., Worley G., Fung E. B., Conaway M. et al. (2002) Bone density and metabolism in children and adolescents with moderate to severe cerebral palsy. Pediatrics IIo, e5.

Jaffe J. S., Timell A. M., Elolia R. \& Thatcher S. S. (2005) Risk factors for low bone mineral density in individuals 
J. J. L. Berkvens et al. - BMD and fractures in children with epilepsy and ID

residing in a facility for the people with intellectual disability. Fournal of Intellectual Disability Research 49, 457-62.

Ko A., Kong J., Samadov F., Mukhamedov A., Kim Y. M., Lee Y. J. et al. (2020) Bone health in pediatric patients with neurological disorders. Annals of Pediatric Endocrinology $\mathcal{E}$ Metabolism 25, I5-23.

Lee R. H., Lyles K. W. \& Colon-Emeric C. (2010) A review of the effect of anticonvulsant medications on bone mineral density and fracture risk. The American fournal of Geriatric Pharmacotherapy 8, 34-46.

Linde J., Molholm Hansen J., Siersbaek-Nielsen K. \& Fuglsang-Fredriksen V. (I97I) Bone density in patients receiving long-term anticonvulsant therapy. Acta Neurologica Scandinavica 47, 650-I.

Marshall W. A. \& Tanner J. M. (I969) Variations in pattern of pubertal changes in girls. Archives of Disease in Childhood 44, 29I-303.

Marshall W. A. \& Tanner J. M. (1970) Variations in the pattern of pubertal changes in boys. Archives of Disease in Childhood 45, 13-23.

Mergler S., Rieken R., Tibboel D., Evenhuis H. M., van Rijn R. R. \& Penning C. (20I2) Lumbar spine and total-body dual-energy X-ray absorptiometry in children with severe neurological impairment and intellectual disability: a pilot study of artefacts and disrupting factors. Pediatric Radiology 42, 574-83.

Mitta N., Rajiv K. R., Baishya J., Chandran A., Menon R., Thomas S. V. et al. (2019) How safe is bone health in patients on newer or enzyme inhibitor antiepileptic drugs? Fournal of the Neurological Sciences 405, II6422.

Rauchenzauner M., Griesmacher A., Tatarczyk T., Haberlandt E., Strasak A., Zimmerhackl L. B. et al. (2010) Chronic antiepileptic monotherapy, bone metabolism, and body composition in non-institutionalized children. Developmental Medicine and Child Neurology 52, $283-8$.

Saraff V. \& Hogler W. (2015) Endocrinology and adolescence: osteoporosis in children: diagnosis and management. European fournal of Endocrinology I73, RI85-97.

Serin H. M., Koc Z. P., Temelli B. \& Esen I. (2015) The bone mineral content alterations in pediatric patients medicated with levetiracetam, valproic acid, and carbamazepine. Epilepsy $\mathcal{E}$ Behavior 5I, $22 \mathrm{I}-4$.

Sharawat I. K. \& Sitaraman S. (20I6) Skeletal maturation and mineralisation of children with moderate to severe spastic quadriplegia. Fournal of Clinical and Diagnostic Research 10, I-5.
Shen C., Chen F., Zhang Y., Guo Y. \& Ding M. (20I4) Association between use of antiepileptic drugs and fracture risk: a systematic review and meta-analysis. Bone 64, 246-53.

Sheth R. D. (2004) Bone health in pediatric epilepsy. Epilepsy \& Behavior 5, S30-5.

Shiek Ahmad B., Hill K. D., O’Brien T. J., Gorelik A., Habib N. \& Wark J. D. (2OI2) Falls and fractures in patients chronically treated with antiepileptic drugs. Neurology 79, I45-5I.

Simm P. J., Biggin A., Zacharin M. R., Rodda C. P., Tham E., Siafarikas A. et al. (2018) Consensus guidelines on the use of bisphosphonate therapy in children and adolescents. Fournal of Paediatrics and Child Health 54, 223-33.

Simm P. J., Seah S., Gorelik A., Gilbert L., Nuguid J., Werther G. A. et al. (2017) Impaired bone and muscle development in young people treated with antiepileptic drugs. Epilepsia 58, I93I-8.

Snoeijen-Schouwenaars F. M., van Deursen K. C., Tan I. Y., Verschuure P. \& Majoie M. H. (2015) Vitamin D supplementation in children with epilepsy and intellectual disability. Pediatric Neurology 52, 160-4.

Tosun A., Erisen Karaca S., Unuvar T., Yurekli Y., Yenisey C. \& Omurlu I. K. (20I7) Bone mineral density and vitamin D status in children with epilepsy, cerebral palsy, and cerebral palsy with epilepsy. Child's Nervous System 33, I53-8.

van den Akker E. (2016) Nederlandse Vereniging voor Kindergeneeskunde - Puberteit. Available at: https:// werkboeken.nvk.nl/emb/Somatische-problematiek/ Endocrinologie/Puberteit (retrieved 27 July 2020).

Verhaar J. A. N. \& van Mourik J. B. A. (2008) Orthopedie, 2nd edn, p. I7r. Bohn Stafleu van Loghum, Houten.

Vestergaard P. (2005) Epilepsy, osteoporosis and fracture risk - a meta-analysis. Acta Neurologica Scandinavica II2, 277-86.

WHO Growth reference 5-I9 years (2007) Available at: http://www.who.int/growthref/who2007_bmi_for_age/en/ (retrieved 27 July 2020).

WHO Epilepsy (2019) Available at: http://www.who.int/en/ news-room/fact-sheets/detail/epilepsy (retrieved 27 July 2020).

Zhang Y., Zheng Y. X., Zhu J. M., Zhang J. M. \& Zheng Z. (2015) Effects of antiepileptic drugs on bone mineral density and bone metabolism in children: a meta-analysis. fournal of Zhejiang University. Science. B I6, 61 I-2 I.

Accepted I9 August 2021 